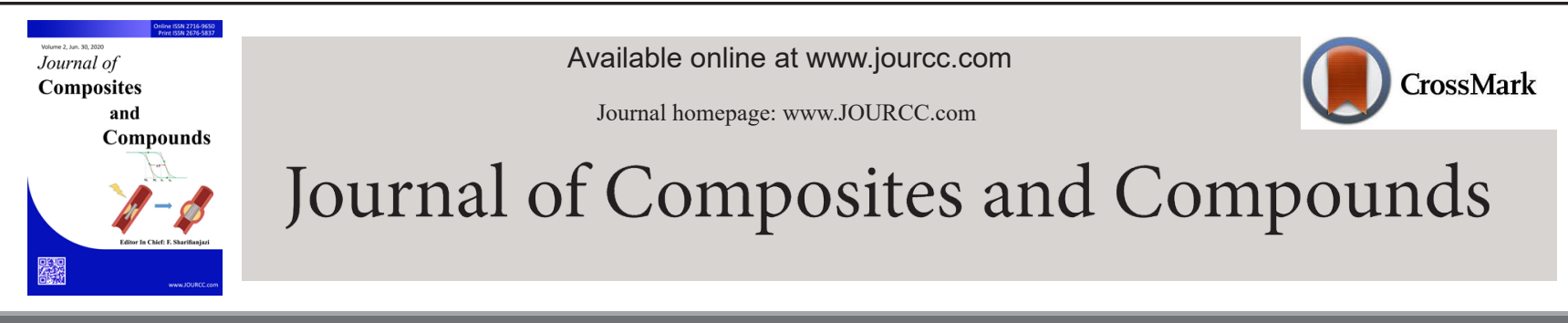

\title{
Sr-doped bioactive glasses for biological applications
}

\author{
Zahra Goudarzi $^{a}$, Amir Ijadi $^{a}$, Ameneh Bakhtiari ${ }^{b *}$, Sara Eskandarinezhad ${ }^{c}$, Negar Azizabadi $^{d *}$, \\ Mohammadreza Asgari Jazi ${ }^{e}$

\begin{abstract}
${ }^{a}$ Department of Mining and Metallurgical Engineering, Amirkabir University of Technology, Tehran, Iran
${ }^{b}$ Department of Biology, Shahid Chamran University, Ahvaz, Iran

${ }^{c}$ Department of Mining and Metallurgical Engineering, Yazd University, Yazd, Iran

${ }^{d}$ Department of Chemistry, Science and Research Branch, Islamic Azad University (IAU), Tehran, Iran

${ }^{e}$ Department of dentistry, Isfahan (khorasgan) Branch, Islamic Azad University (IAU), Isfahan, Iran
\end{abstract}

\begin{abstract}
A B S T R A C T
A R T I C LE IN F O RM A T ION

In this work, sol-gel derived bioactive glasses (BGs) system of $60 \% \mathrm{SiO}_{2}-(36-\mathrm{x}) \mathrm{CaO}-4 \mathrm{P}_{2} \mathrm{O}_{5}-\mathrm{x}$ SrO (where $\mathrm{x}=2$, Article history:

4, 6 and $8 \mathrm{~mol} \%$ ) were obtained. The bioactivity and proliferation of G292 cells was investigated for Sr-contain- Received 6 June 2020

ing BGs. X-ray diffraction analysis (XRD), Scanning electron microscopy (SEM) and Fourier transform infrared Received in revised form 17 June 2020

spectroscopy (FTIR) were utilized to study the obtained phases, hydroxyapatite (HA) morphology, and its func- Accepted 29 June 2020

tional groups, respectively. The XRD and FTIR tests showed that the rate of hydroxyapatite formation on sample

2S was higher than that of other samples. Also 3-(4,5 dimethylthiazol-2-yl)-2,5-diphenyltetrazolium bromide Keywords:

(MTT) assay performed after one day revealed that the sample containing $6 \mathrm{~mol} \%$ of $\mathrm{Sr}(6 \mathrm{~S})$ showed higher Bioactive glass

viability. However, the sample with $8 \mathrm{~mol} \% \mathrm{Sr}(8 \mathrm{~S})$ showed a decrease in bioactivity in osteoblast G292 cells Implant

proliferation. According to the results, $6 \mathrm{~S}$ BG specimen with $6 \mathrm{~mol} \% \mathrm{SrO}$ exhibited appropriate bioactivity and Strontium

cell proliferation. This finding showed that the obtained BGs could be potentially used for drug delivery systems Drug delivery

as well as dental and orthopedic applications.

C2020 JCC Research Group.

Peer review under responsibility of JCC Research Group
\end{abstract}

\section{Introduction}

From the beginning, in medicine and surgery, bone problems have been important issues up to recent years. For this purpose, the first generation of biomaterials (i.e. metals and alloys) was introduced and made available to surgeons [1-3]. Nevertheless, implanting metal and alloys in the body can be inefficient and hurmful [3].

On the other hand, many problems can emerge with some bonds, such as autophagy, allograft, xenograft. Thus scientists have focused on designing advanced materials to make appropriate alternatives. Due to the above-mentioned problems, as well as the use of repeated and relatively unsuccessful surgeries in this field, the academic focus turned to the production and replacement of materials with compounds that do not harm healthy tissue. For the first time, Hench [4] developed a combination of bioactive glass that was compatible with the environment and was gradually attached to bone tissue. After that, new compounds with different properties were produced and expanded [1, 5-7].

After his great discovery, the progress and development of glass was categorized in four era: The era of Discovery (1969 to 1979), Era of Clinical Application (1980 to 1995), Era of Tissue Regeneration (1995 to 2005), and Era of Innovation (2005 to 2025). After that Wilson et al.
[8], announced that they had found a glass that not only bonds to hard tissues, but also could bond to soft tissue. This was a new feature that led to widespread "clinical use" of glasses, such as middle ear replacement prostheses (MEP) and endosseous ridge maintenance implants (ERMI). They reported that for a range of glass particle sizes, there is an optimum for bone regeneration rate. Also, the rate of new bone formation is so high that the encapsulation of the site would be prevented by epithelial tissues [9]. Until 1992, the glass was often produced by melting, and most research was done on bioactive glass $45 \mathrm{~s} 5$. In the melting method, a combination of oxides and additives is melted by increasing the temperature and after cooling, they are crushed and used as particles.

The problem with the melting method is high-temperature work and evaporation (volatile component) at this temperature. In this regard, in recent years, extensive research has been done on the sol-gel route as an alternative to the melting method $[10,11]$.

The sol-gel method can make very homogeneous composites with very high purity. It is also able to produce ceramic and metallic nanomaterials at much lower temperatures than conventional methods that have very high-temperature ranges. Due to the above-mentioned advantages, it can be considered as a suitable method for producing the compounds especially nanomaterials [12]. 
Table 1.

Studies worked on Sr-containing BGs.

\begin{tabular}{|c|c|c|c|}
\hline BG system & Synthesis route & $\begin{array}{c}\text { Time of HA formation af- } \\
\text { ter soaking in SBF solution }\end{array}$ & Ref. \\
\hline $\begin{array}{c}\text { Sr-BGs }(0,5,10) \\
\text { Sr-BGs }(0,2,5,8 \\
\text { and } 10)\end{array}$ & Sol-gel process & all samples after 3 days & {$[31]$} \\
\hline
\end{tabular}

Currently, many glasses are made on the basis of the main ingredients of $\mathrm{SiO}_{2}, \mathrm{P}_{2} \mathrm{O}_{5}, \mathrm{CaO}$ [13-17]. $\mathrm{SiO}_{2}$ acts as a network former in the structure of glass, and its release into the environment can positively affect the cell activity and proliferation [18-24]. Ca and $\mathrm{P}$ are also useful as factors in the nucleation of calcium phosphate phases such and hydroxyapatite (HA) $[15,25]$. Other elements (viz. Mg, $\mathrm{Zn} \mathrm{Ag,} \mathrm{etc.)} \mathrm{are} \mathrm{added}$ to the glass structure to enhance other properties such as antibacterial, cell proliferation and other biological properties [7, 26-30]. Meanwhile, $\mathrm{Sr}$ as a promising element for cell proliferation has been doped into the BGs. Table 1 shows two important works about Sr-doped BGs.

Table 1 .

Therefore, since there are insufficient research about doping of $\mathrm{Sr}$ in the BGs, in this study, we used different amounts of $\mathrm{Sr}(2,4,6$, and $8 \mathrm{~mol} . \%$ ) to investigate the biocompatibility of the BGs. It is reported that the BGs can be potentially applied for implant and orthopedic applications [32].

\section{Materials and methods}

\subsection{Materials and regents}

Table 2 lists the details about the chemical composition of the synthesized BGs. Tetraethylorthosilicate (TEOS: $\left.\mathrm{Si}\left(\mathrm{OC}_{2} \mathrm{H}_{5}\right)_{4}\right)$, calcium nitrate $\mathrm{Ca}\left(\mathrm{NO}_{3}\right)_{2}, 4 \mathrm{H}_{2} \mathrm{O}$, triethyl phosphate (TEP: $\left.\mathrm{PO}\left(\mathrm{OC}_{2} \mathrm{H}_{5}\right)_{3}\right)$, and strontium nitrate $\mathrm{Sr}\left(\mathrm{NO}_{3}\right)_{2}$ were used as the source of silicon, calcium, phosphorus, and strontium, respectively (bought from the Merck Company, Germany).

Table 2.

\subsection{Synthesis of $B G S$}

The BGs in the $\mathrm{SiO}_{2}-\mathrm{CaO}-\mathrm{P}_{2} \mathrm{O}_{5}-\mathrm{SrO}$ system were obtained using the sol-gel route. A $0.1 \mathrm{M}$ nitric acid solution was provided and TEOS was added into the solution and stirring was applied for 45 minutes at 25 ${ }^{\circ} \mathrm{C}$ for hydrolysis of the acid. TEP, strontium nitrate, and calcium nitrate were poured into the TEOS solution, and each reagent was maintained for $30 \mathrm{~min}$ to complete the hydrolysis process. In the following, the mixture was further stirred for 50 minutes to let the reactions be completed, so that a sol was obtained. The sol was sealed for 3 days at $37^{\circ} \mathrm{C}$ and dried for 1 day at $75^{\circ} \mathrm{C}$ to obtain a dried gel. In order to calcine the dried gel, it was maintained in a furnace at $800{ }^{\circ} \mathrm{C}$ for $3 \mathrm{~h}$ so that the organic substances and nitrates are eliminated. In the next step, a planetary ball mill was utilized to grind the prepared product into a fine powder so that their size become below $50 \mu \mathrm{m}$ and pressed into disks (weight of $0.5 \mathrm{~g}$, height of $2 \mathrm{~mm}$ and diameter of $17 \mathrm{~mm}$ ) under $10 \mathrm{MPa}$ by ACM device. Finally, the samples were prepared to be evaluated in-vitro.

Table 2.

Chemical composition and sample coding of all BGs

\begin{tabular}{ccccc}
\hline $\begin{array}{c}\text { Bioglass } \\
\text { code }\end{array}$ & $\begin{array}{c}\mathrm{SiO}_{2} \\
(\mathbf{m o l .} \%)\end{array}$ & $\begin{array}{c}\mathrm{P}_{2} \mathrm{O}_{5} \\
(\mathbf{m o l} \%)\end{array}$ & $\begin{array}{c}\mathrm{CaO} \\
(\mathbf{m o l .} \%)\end{array}$ & $\begin{array}{c}\mathrm{SrO} \\
(\mathbf{m o l} \%)\end{array}$ \\
\hline $\mathrm{S} 2$ & 60 & 4 & 34 & 2 \\
$\mathrm{~S} 4$ & 60 & 4 & 32 & 4 \\
$\mathrm{~S} 6$ & 60 & 4 & 30 & 6 \\
$\mathrm{~S} 8$ & 60 & 4 & 28 & 8 \\
\hline
\end{tabular}

\subsection{Simulated body fluid (SBF) preparation}

The SBF solution is similar to the inorganic part of human plasma that was prepared based on the procedure explained by Kokubo [33]. All chemical reagents were bought from Merck Company, Germany. $\mathrm{NaOH}$, $\mathrm{KCl}, \mathrm{NaHCO}_{3} \mathrm{MgCl}_{2} \cdot 6 \mathrm{H}_{2} \mathrm{O}, \mathrm{CaCl}_{2}$ and $\mathrm{KH}_{2} \mathrm{PO}_{4}$ were used as reagents and dissolved in deionized water. A buffered solution was prepared with the mentioned solution and tris(hydroxymethyl) aminomethane, $\left(\mathrm{HOCH}_{2}\right)_{3} \mathrm{CNH}_{2}$. Next, the $\mathrm{pH}$ was adjusted to 7.4 by $\mathrm{HCl}$.

\subsection{Bioactive glass characterization}

\subsubsection{Thermal analysis}

In order to predict the thermal behavior of the samples as a function of temperature, the dried gel of $4 \mathrm{~S}$ sample was applied for DTA test. During the test, a reference sample was placed in the device along with the samples to determine the temperature of the sample change phase. The obvious feature of the reference sample is that it does not show any phase change during temperature rise. For this purpose, alumina is commonly used in most devices. The tests were performed via Simultaneous Thermal Analysis (STA) (PL-STA 1640), in the range of 30-800 ${ }^{\circ} \mathrm{C}$ under normal atmosphere, along with an increasing temperature rate of $5{ }^{\circ} \mathrm{C}$ per min.

\subsubsection{X-ray diffraction (XRD) test}

In order to evaluate the phases formed on the glass surface and to ensure the presence of hydroxyapatite, the surfaces of samples were studied by XRD (INEL-Equinox-3000) with the $\mathrm{Cu} \mathrm{K \alpha}$ radiation with wavelength of $1.540510 \AA$ by voltage and current of $40 \mathrm{kV}$ and $30 \mathrm{~mA}$. The patterns were recorded in the $2 \theta$ range of $20^{\circ}$ to $90^{\circ}$ via a scanning speed of $2 \% \mathrm{~min}$.

\subsubsection{Fourier-transform infrared spectroscopy analysis}

After soaking of the samples in SBF, their surfaces were characterized by FTIR (Bomem MB 100 instrument). In this regard, the glass powders and potassium bromide were mixed with 1:100 ratio. The transmittance mode of spectra was obtained in the range of $400-4000 \mathrm{~cm}^{-1}$ by the resolution of $4 \mathrm{~cm}^{-1}$.

\subsubsection{PH measurement}

On different days of immersion, the $\mathrm{pH}$ change was measured via $\mathrm{pH}$ meter (Corning $\mathrm{pH}$ meter 340).

\subsubsection{SEM analysis}

The morphology of the formed hydroxyapatite was examined using SEM analysis (SEM, Philips XL30, Netherlands) with a voltage of 20 $\mathrm{kV}$.

\subsection{MTT assay}

Cell proliferation was measured using the MTT (Sigma, USA) assay after treating for 1,3 and 7 days. MTT solution $(20 \mu \mathrm{L})$ was added to wells. Cells lines of G292 osteoblast were bought from the National Cell Bank of Iran (Pasteur Institute, Iran). The cells were cultured and incubated for 1 day under conditions of $90 \%$ humidity and $37{ }^{\circ} \mathrm{C}$, followed by seeding in small plates (with density of $6 \times 10^{4}$ cells/well). The wavelength absorbance of the well-plates during the reactions, were elucidated via EL 312e Biokinetics reader, Biotek Instruments. Each measurement was performed in triplicates. 


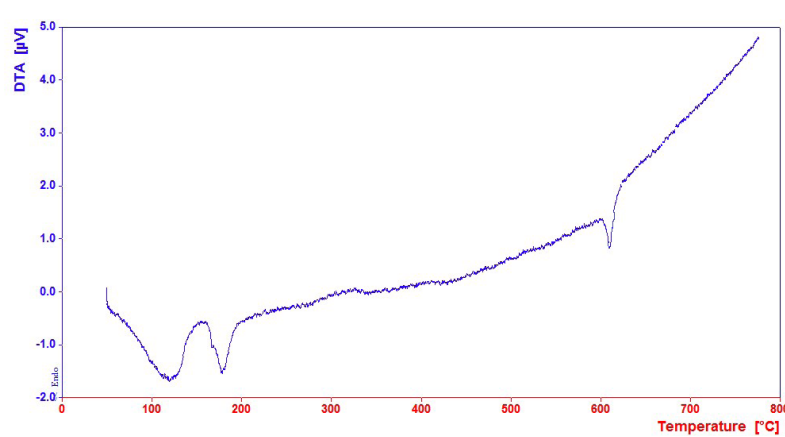

Fig. 1. DTA curve of synthesized 4S sample.

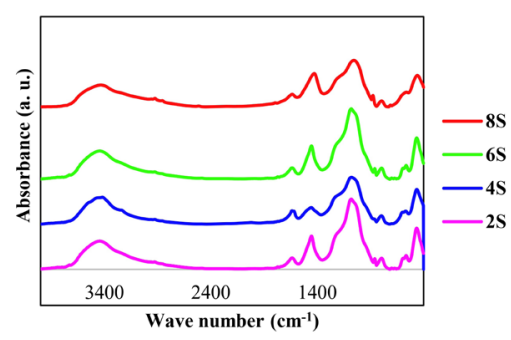

Fig. 3. The FTIR spectra of the BG samples after immersing in SBF solution for 3 days.

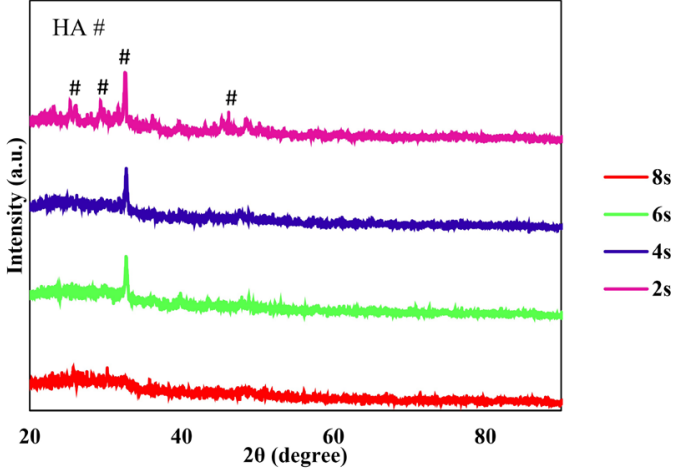

Fig. 2. XRD spectra of the BGs after soaking in SBF solution for 3 days.

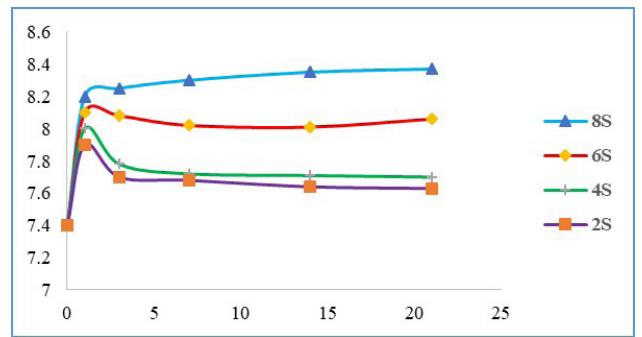

Fig. 4. Changes in $\mathrm{pH}$ of SBF solution over time in glasses containing strontium oxide.

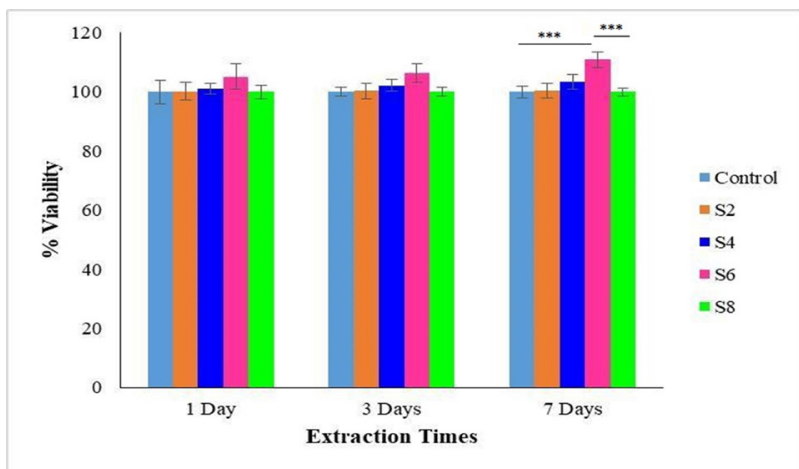

Fig. 5. Cytotoxicity of BG samples after exposure to osteoblastic G292 cells after 1, 3, and 7 days.

\section{Results and discussion}

\subsection{Thermal analysis}

The DTA curve of 4S bioactive glass is shown in Fig. 1. Accordingly, the endothermic peak is observable at $114{ }^{\circ} \mathrm{C}$, in which the physically adsorbed water is removed. The next endothermic peak occurs at 220 ${ }^{\circ} \mathrm{C}$, which is related to the removal of the sample chemical absorbance of water. The peak for silane and nitrate removal is observable at 600 ${ }^{\circ} \mathrm{C}$. The results showed that all residuals were removed at $600{ }^{\circ} \mathrm{C}$. This suggested that $700{ }^{\circ} \mathrm{C}$ was appropriate for BGs stabilization.

\subsection{Phase analysis}

Fig. 2 shows XRD patterns of the BGs after 3 days of immersion. It is obvious that, except $8 \mathrm{~S}$ sample, the peaks related to hydroxyapatite were obvious. Therefore, by increasing the amount of strontium, the tendency to form crystalline apatite has decreased. Also, the peaks observed in the XRD spectra of samples S2, S4 and S6 at $2 \theta=31.8^{\circ}$ (attributed to the (211) plane) confirmed the crystalline hydroxyapatite formation (JCPDS 09-432). Besides, the intensity of the peak at 2 theta of $31.9^{\circ}$ in the XRD spectrum of $2 \mathrm{~S}$ sample is higher than other samples, which is due to the greater tendency of the sample to form hydroxyapatite on its surface.
3.3. FTIR

The FTIR spectra of the BG samples are presented in Fig. 3. According to the Fig. 3, after 3 days of immersion, two peaks about 1455 and $870 \mathrm{~cm}^{-1}$ emerged in the XRD patterns of all samples that are attributed to carbonate $(\mathrm{C}-\mathrm{O}$ stretching) groups. The presence of hydroxyapatite was confirmed by existence of three peaks at 566,603 , and $1087 \mathrm{~cm}^{-1}$. Besides, stretching and bending vibrations of $\mathrm{Si}-\mathrm{O}-\mathrm{Si}$ were also observed in the FTIR spectra of samples (i.e. $430 \mathrm{~cm}^{-1}$ ) [34]. Meanwhile, the intensity of mentioned peaks was higher for $2 \mathrm{~S}$ sample than that of other samples. Finally, FTIR results depicted that Sr retarded the formation of HA phase.

\subsection{Measurement of $p H$}

Fig. 4 shows the $\mathrm{pH}$ changes. The $\mathrm{pH}$ changes of the SBF solution were measured after 1, 3, 7, 14, and 21 days of immersion. Studies have shown that $\mathrm{Ca}$ and $\mathrm{Sr}$ exchange ions with $\mathrm{H}^{+}$, so the presence of these two cations in the composition is expected to make the $\mathrm{pH}$ of the solution increase at the time of immersion. Exchange of $\mathrm{Ca}^{2+}$ glass with soluble $\mathrm{H}_{3} \mathrm{O}^{+}$results in the formation of $\mathrm{OH}-\mathrm{Si}$ bands on the glass surface, encourages the formation of apatite, and creates a suitable environment for apatite crystallization. After a time, the rate of increase in $\mathrm{pH}$ decreases, which means that silica-rich layers are created, and the cation exchange and release of calcium is prevented. The highest $\mathrm{pH}$ is related 


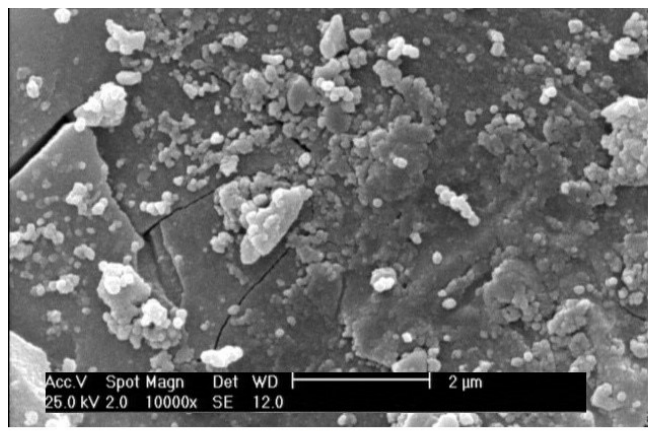

(a)

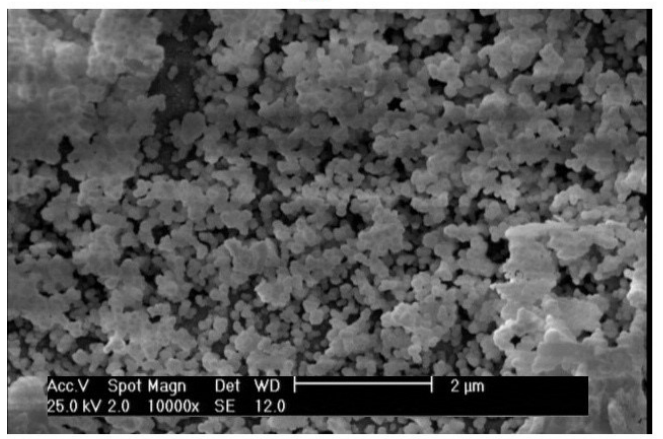

(c)

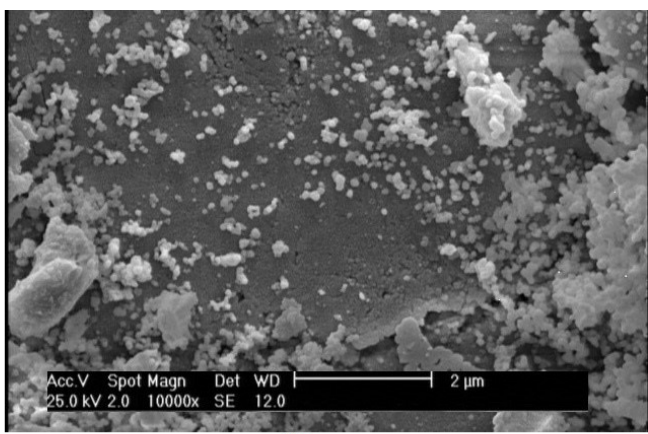

(b)

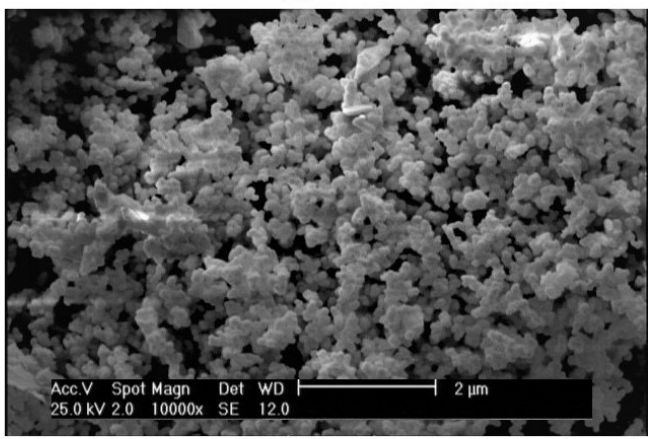

(d)
Fig. 6. SEM micrographs of S6 BG sample after soaking in the SBF solution for (a) 3, (b) 7, (c) 14 and (d) 21 days. to the $8 \mathrm{~S}$ sample due to the high Sr level.

\subsection{Cell proliferation}

Fig. 5 depicts the MTT results of cultured osteoblast G292 cells that contain samples of control, S2, S4, S6, and S8 incubated for 1, 3 and, 7 days. It can be seen that viability of S6 increased by an increment in the soaking time up to $7^{\text {th }}$ day $(* * * \mathrm{P}<0.001)$. Thus, they led to an increment in cell differentiation and proliferation. The cell viability of S2 and S4 samples, on the other hand, was not significantly different. Also, significantly lower cell proliferation was illustrated by the S8 sample in comparison to $\mathrm{S} 6(* * * \mathrm{P}<0.001)$. Thus, the obtained MTT results suggested that the incorporation of $6 \% \mathrm{Sr}$ in $\mathrm{BG}$ composition would significantly improve the cell proliferation, while $8 \% \mathrm{Sr}$ showed no significant positive effect. Thus, based on the data, S6 was selected as the best BG sample.

\subsection{SEM}

Fig. 6 shows the process of hydroxyapatite formation after different days of immersion on the S6 sample (with the optimum sample composition). It is obvious that some parts of the surface is covered by small spherical particles of apatite after 3 days of soaking (Fig. 6(a)). As the immersion time in solution increases, the density of HA particles also increase (Fig. 6(b), (c), and 6(d)). It is obvious that on 21st day of soaking, the surface of BG is completely covered with hydroxyapatite.

\section{Conclusions}

The $\mathrm{SiO}_{2}-\mathrm{P}_{2} \mathrm{O}_{5}-\mathrm{CaO}-\mathrm{SrO} \mathrm{BG}$ system was fabricated through sol-gel method. The results of this study are as follows:

- XRD and FTIR analyses confirmed that after 3 days in all samples, except $8 \mathrm{~S}$, the peaks related to hydroxyapatite emerged.

- MTT in-vitro test showed that after 7 days of incubation, S6 sample showed a statistically significant increase in viability of osteoblast G292 cells.

- The presence of $\mathrm{Sr}$ in $\mathrm{BG}$ composition increases the $\mathrm{pH}$ of simulated body fluid.

- SEM results showed that the apatite morphology was spherical on the S6 BG sample surface. It was also found that as the immersion time in the SBF increases, the density of HA particles increases.

- According to the results, the sample S6 was selected as the optimum sample in terms of bioactivity and cell proliferation that can be potentially used for drug delivery systems as well as orthopedic and dental applications.

\section{Acknowledgments}

The authors thank the Research Committee of Islamic Azad University (Isfahan (khorasgan) and Science and Research Branch), Yazd University (Department of Mining and Metallurgical Engineering), Shahid Chamran University (Biology Department) and Amirkabir University of Technology (Department of Mining and Metallurgical Engineering) for financial support of this work.

\section{Conflict of Interest}

All authors declare no conflicts of interest in this paper.

\section{REFERENCES}

[1] L.L. Hench, The story of Bioglass ${ }^{\circledR}$, Journal of Materials Science: Materials in Medicine 17(11) (2006) 967-978.

[2] J.R. Jones, New trends in bioactive scaffolds: The importance of nanostructure, Journal of the European Ceramic Society 29(7) (2009) 1275-1281.

[3] E. Rezabeigi, P.M. Wood-Adams, R.A. Drew, Synthesis of 45S5 Bioglass ${ }^{\circledR}$ via a straightforward organic, nitrate-free sol-gel process, Materials Science and Engineering: C 40 (2014) 248-252.

[4] L.L. Hench, The theory of bioactive bonding, Mat. Clin. Appl (1995) 331-342. [5] Q. Nawaz, M.A. Ur Rehman, J.A. Roether, L. Yufei, A. Grünewald, R. Detsch, A.R. Boccaccini, Bioactive glass based scaffolds incorporating gelatin/manganese doped mesoporous bioactive glass nanoparticle coating, Ceramics International 45(12) (2019) 14608-14613.

[6] F. Baino, E. Fiume, M. Miola, F. Leone, B. Onida, E. Verné, Fe-doped bioactive glass-derived scaffolds produced by sol-gel foaming, Materials Letters 235 (2019) 207-211.

[7] N. Pajares-Chamorro, J. Shook, N.D. Hammer, X. Chatzistavrou, Resurrec-tion of antibiotics that methicillin-resistant Staphylococcus aureus resists by sil-verdoped bioactive glass-ceramic microparticles, Acta Biomaterialia 96 (2019) 537-546.

[8] L. Hench, J. Wilson, Bioactive materials, MRS Online Proceedings Library 
Archive 55 (1985)

[9] L.L. Hench, J.R. Jones, Bioactive glasses: frontiers and challenges, Frontiers in bioengineering and biotechnology 3 (2015) 194

[10] F. Sharifianjazi, N. Parvin, M. Tahriri, Synthesis and characteristics of solgel bioactive $\mathrm{SiO}_{2}-\mathrm{P}_{2} \mathrm{O}_{5}-\mathrm{CaO}-\mathrm{Ag}_{2} \mathrm{O}$ glasses, Journal of Non-Crystalline Solids 476 (2017) 108-113.

[11] F. Sharifianjazi, N. Parvin, M. Tahriri, Formation of apatite nano-needles on novel gel derived $\mathrm{SiO}_{2}-\mathrm{P}_{2} \mathrm{O}_{5}-\mathrm{CaO}-\mathrm{SrO}-\mathrm{Ag}_{2} \mathrm{O}$ bioactive glasses, Ceramics Interna-tional 43(17) (2017) 15214-15220.

[12] L.L. Hench, J.K. West, The sol-gel process, Chemical reviews 90(1) (1990) 33-72.

[13] R. Orifice, L. Hench, A. Clark, A. Brennan, Novel sol-gel bioactive fibres, J Biomed Mater Res 55 (2001) 460-467.Fig. 6. SEM micrographs of S6 BG sample after soaking in the SBF solution for (a) 3, (b) 7, (c) 14 and (d) 21 days.

[14] A. Salinas, A. Martin, M. Vallet-Regí, Bioactivity of three $\mathrm{CaO}-\mathrm{P}_{2} \mathrm{O}_{5}-\mathrm{SiO}-$ 2sol-gel glasses, Journal of Biomedical Materials Research: An Official Journal of The Society for Biomaterials, The Japanese Society for Biomaterials, and The Australian Society for Biomaterials and the Korean Society for Biomaterials 61(4) (2002) 524-532.

[15] P. Saravanapavan, J.R. Jones, R.S. Pryce, L.L. Hench, Bioactivity of gel-glass powders in the $\mathrm{CaO}-\mathrm{SiO}_{2}$ system: A comparison with ternary $\left(\mathrm{CaO}-\mathrm{P}_{2} \mathrm{P}_{5}-\mathrm{SiO}_{2}\right)$ and quaternary glasses $\left(\mathrm{SiO}_{2}-\mathrm{CaO}-\mathrm{P}_{2} \mathrm{O}_{5}-\mathrm{Na}_{2} \mathrm{O}\right)$, Journal of Biomedical Materials Research Part A: An Official Journal of The Society for Biomaterials, The Japanese Society for Biomaterials, and The Australian Society for Biomaterials and the Korean Society for Biomaterials 66(1) (2003) 110-119

[16] A. Moghanian, A. Ghorbanoghli, M. Kazem-Rostami, A. Pazhouheshgar, E. Salari, M. Saghafi Yazdi, T. Alimardani, H. Jahani, F. Sharifian Jazi, M. Tahriri, Novel antibacterial $\mathrm{Cu} / \mathrm{Mg}$-substituted 58S-bioglass: Synthesis, characterization and investigation of in vitro bioactivity, International Journal of Applied Glass Science $\mathrm{n} / \mathrm{a}(\mathrm{n} / \mathrm{a})(2019)$

[17] M.S.N. Shahrbabak, F. Sharifianjazi, D. Rahban, A. Salimi, A Comparative Investigation on Bioactivity and Antibacterial Properties of Sol-Gel Derived 58S Bioactive Glass Substituted by Ag and Zn, Silicon 11(6) (2019) 2741-2751.

[18] P.V. Phan, M. Grzanna, J. Chu, A. Polotsky, A. El-Ghannam, D. Van Heerden, D.S. Hungerford, C.G. Frondoza, The effect of silica-containing calcium-phosphate particles on human osteoblasts in vitro, Journal of Biomedical Materials Research Part A: An Official Journal of The Society for Biomaterials, The Japa-nese Society for Biomaterials, and The Australian Society for Biomaterials and the Korean Society for Biomaterials 67(3) (2003) 1001-1008.

[19] L.L. Hench, An introduction to bioceramics, World scientific1993.

[20] T. Kokubo, H. Kushitani, S. Sakka, T. Kitsugi, T. Yamamuro, Solutions able to reproduce in vivo surface-structure changes in bioactive glass-ceramic A-W3, Journal of biomedical materials research 24(6) (1990) 721-734.

[21] A.M. Pietak, J.W. Reid, M.J. Stott, M. Sayer, Silicon substitution in the calci-um phosphate bioceramics, Biomaterials 28(28) (2007) 4023-4032.

[22] M. Barekat, R.S. Razavi, F. Sharifianjazi, Synthesis and the surface resistivity of carbon black pigment on black silicone thermal control coating, Synthesis and Reactivity in Inorganic, Metal-Organic, and Nano-Metal Chemistry 45(4) (2015)
$502-506$.

[23] E. Ghasali, A. Bordbar-Khiabani, M. Alizadeh, M. Mozafari, M. Niazmand, H. Kazemzadeh, T. Ebadzadeh, Corrosion behavior and in-vitro bioactivity of porous $\mathrm{Mg} / \mathrm{Al}_{2} \mathrm{O}_{3}$ and $\mathrm{Mg} / \mathrm{Si}_{3} \mathrm{~N}_{4}$ metal matrix composites fabricated using microwave sintering process, Materials Chemistry and Physics 225 (2019) 331-339.

[24] S. Rahimi, F. SharifianJazi, A. Esmaeilkhanian, M. Moradi, A.H. Safi Samgh-abadi, Effect of $\mathrm{SiO}$ content on $\mathrm{Y}-\mathrm{TZP} / \mathrm{Al}_{2} \mathrm{O}_{3}$ ceramic-nanocomposite proper-ties as potential dental applications, Ceramics International 46(8, Part A) (2020) 10910-10916.

[25] A. Esmaeilkhanian, F. Sharifianjazi, A. Abouchenari, A. Rouhani, N. Parvin, M. Irani, Synthesis and Characterization of Natural Nano-hydroxyapatite Derived from Turkey Femur-Bone Waste, Applied Biochemistry and Biotechnology 189(3) (2019) 919-932.

[26] A. Balamurugan, G. Balossier, J. Michel, S. Kannan, H. Benhayoune, A. Re-belo, J. Ferreira, Sol gel derived $\mathrm{SiO}_{2}-\mathrm{CaO}-\mathrm{MgO}-\mathrm{P}_{2} \mathrm{O}_{5}$ bioglass systemPrepara-tion and in vitro characterization, Journal of Biomedical Materials Research Part B: Applied Biomaterials: An Official Journal of The Society for Biomaterials, The Japanese Society for Biomaterials, and The Australian Society for Biomaterials and the Korean Society for Biomaterials 83(2) (2007) 546-553.

[27] Z. Goudarzi, N. Parvin, F. Sharifianjazi, Formation of hydroxyapatite on surface of $\mathrm{SiO}_{2}-\mathrm{P}_{2} \mathrm{O}_{5}-\mathrm{CaO}-\mathrm{SrO}-\mathrm{ZnO}$ bioactive glass synthesized through sol-gel route, Ceramics International 45(15) (2019) 19323-19330.

[28] S. Hesaraki, M. Gholami, S. Vazehrad, S. Shahrabi, The effect of Sr con-centration on bioactivity and biocompatibility of sol-gel derived glasses based on $\mathrm{CaO}-\mathrm{SrO}-\mathrm{SiO}_{2}-\mathrm{P}_{2} \mathrm{O}_{5}$ quaternary system, Materials Science and Engineering: $\mathrm{C}$ 30 (3) (2010) 383-390.

[29] A. Oki, B. Parveen, S. Hossain, S. Adeniji, H. Donahue, Preparation and in vitro bioactivity of zinc containing sol-gel-derived bioglass materials, Journal of Biomedical Materials Research Part A: An Official Journal of The Society for Bio-materials, The Japanese Society for Biomaterials, and The Australian Society for Biomaterials and the Korean Society for Biomaterials 69(2) (2004) 216-221.

[30] F. Sharifianjazi, M. Moradi, A. Abouchenari, A.H. Pakseresht, A. Esmaeilkha-nian, M. Shokouhimehr, M.S. Asl, Effects of $\mathrm{Sr}$ and Mg dopants on biological and mechanical properties of $\mathrm{SiO}_{2}-\mathrm{CaO}-\mathrm{P}_{2} \mathrm{O}_{5}$ bioactive glass, Ceramics International (2020)

[31] A.H. Taghvaei, F. Danaeifar, C. Gammer, J. Eckert, S. Khosravimelal, M. Gholipourmalekabadi, Synthesis and characterization of novel mesoporous stron-tium-modified bioactive glass nanospheres for bone tissue engineering applica-tions, Microporous and Mesoporous Materials 294 (2020) 109889

[32] F. Sharifianjazi, A.H. Pakseresht, M. Shahedi Asl, A. Esmaeilkhanian, H. Nar-gesi khoramabadi, H.W. Jang, M. Shokouhimehr, Hydroxyapatite Consolidated by Zirconia: Applications for Dental Implant, Composites and Compounds 2(1) (2020).

[33] T. Kokubo, H. Takadama, How useful is SBF in predicting in vivo bone bio-activity?, Biomaterials 27(15) (2006) 2907-2915.

[34] A. Moghanian, S. Firoozi, M. Tahriri, Characterization, in vitro bioactivity and biological studies of sol-gel synthesized $\mathrm{SrO}$ substituted $58 \mathrm{~S}$ bioactive glass, Ceramics International 43(17) (2017) 14880-14890. 